\title{
A performance pós-moderna de Nélida Piñon contra o feminicídio em Vozes do deserto*
}

Carlos Magno Gomes**

\section{Resumo}

Este artigo apresenta um estudo sobre as estratégias de resistência contra o feminicídio no romance pós-moderno Vozes do deserto (2004), de Nélida Piñon. Essa obra, além de retomar o imaginário árabe, descreve a luta feminista da protagonista, Scherezade, por liberdade e pelo fim da execução das esposas do Califa, possibilitando um debate aprofundado sobre o sacrifício feminino como parte de uma estrutura social de manutenção do poder masculino por meio da violência de gênero. Esse poder se impõe por meio de assédios, de agressões físicas e da tirania da execução da esposa/companheira, quando fora dos padrões morais impostos pelos valores patriarcais, conforme os estudos antropológicos de Rita Laura Segato, Henrietta Moore e Lia Zanotta Machado.

Palavras-chave: Feminicídio, Intertextualidade, Estudos Feministas.

* Recebido em 20 de abril de 2017, aceito em 3 de abril de 2018.

** Professor de Teoria Literária, Universidade Federal de Sergipe/CNPq, São Cristóvão, SE, Brasil. calmag@bol.com.br / http://orcid.org/0000-0001-9070$\underline{9010}$ 
The Postmodern Performance of Nélida Piñon against Femicide in "Vozes do Deserto"

\begin{abstract}
This article presents a study about strategies of resistance against femicide in the postmodern novel "Vozes do deserto" (2004), by Nélida Piñon. This work, in addition to reviving the Arab imagery, describes the feminist struggle of Scheherazade, for freedom and for the end of the execution of the Caliph's wives. This enables a profound debate about female sacrifice as part of a social structure of maintaining male power through gender violence. This power is imposed by harassment, physical aggression, and the tyranny of the execution of wives and companions when outside the moral standards imposed by the patriarchal values, according to the anthropological studies of Rita Laura Segato, Henrietta Moore and Lia Zanotta Machado.
\end{abstract}

Keywords: Femicide, Intertextuality, Feminist Studies. 


\section{Introdução}

A abordagem antropológica de base feminista questiona as diferentes formas de violência de gênero como parte da regulamentação das normas sociais. As agressões físicas $e$ psicológicas sofridas por mulheres, em relações afetivas ou no espaço público, funcionam como dispositivos sociais destinados a manter o poder masculino, nos quais se padroniza, simbolicamente, o feminino como inferior $e$ as mulheres como "vítimas preferenciais e crônicas da força física ou da violação sexual" (Machado, 2010:62). No contexto familiar, a violência contra a mulher é explorada como um mecanismo de controle e de ameaça imaginária, visto que "esposas são muitas vezes espancadas por infidelidades imaginárias, o que torna a violência e a ameaça de violência mais eficaz como meio de controle social" (Moore, 2000:39).

Essas normas, em contextos sociais patriarcais, são, muitas vezes, incorporadas como mecanismos disciplinadores $e$ perpassam concepções populares que dão respaldo aos valores masculinos como hegemônicos. Tais valores fazem parte dos meandros de diversas formas de violência de gênero, incorporadas a práticas sociais cotidianas. Para Segato, essa violência dá sustentação ao processo simbólico de controle masculino sobre o corpo da mulher e pode ser identificada como "física, psicológica e sexual, além da violência estrutural reproduzida pelas vias da discriminação nos campos econômico e social" (2003:02).

Assim como nas relações sociais, as representações da violência de gênero na literatura estão atravessadas por questões subjetivas e pela estrutura simbólica que privilegia a dominação masculina. Nos últimos anos do século XX, as escritoras brasileiras incorporaram diferentes recursos estéticos que, ao mesmo tempo que renovaram a estrutura romanesca, questionaram a violência de gênero tanto em espaços urbanos, em que o agressor é um estranho, como nos domésticos, em que a mulher é vítima do companheiro. A perspectiva questionadora pode ser identificada na construção estética e nos múltiplos sentidos de obras que 
exploram a perversão masculina como mecanismo de manutenção de poder.

Nos anos 1970, Lygia Fagundes Telles ironiza a mente criminosa de um rapaz que não aceita o fim da relação e aprisiona a ex-namorada em um cemitério abandonado na tentativa de enterrá-la viva no conto "Venha ver o pôr do sol", da coletânea Antes do baile verde (1970). Nessa mesma década, Clarice Lispector questiona a dupla violência que as mulheres sofrem ao denunciarem o estupro: a violência sexual e a social, quando, após sofrer o assédio verbal e/ou a violação do corpo, a mulher ainda é culpada por não se comportar adequadamente no conto a "A língua do 'P'", da coletânea A via crucis do corpo (1974). Esses dois contos expõem uma concepção machista construída por meio do perverso culto da honra masculina e da virilidade compulsiva conforme estudos de Gomes (2014) acerca do feminicídio na literatura brasileira.

$\mathrm{Na}$ década seguinte, o primeiro romance de Lya Luft nos impressiona pela força de sua narrativa que denuncia o estupro como um ato corriqueiro de um casamento em que a matriarca de uma família de mulheres era estuprada pelo avô da narradora em As parceiras (1980). Nessa obra, Luft propõe o resgate das memórias familiares como uma maneira de questionar a tirania das relações sexuais impostas com uma prerrogativa: a satisfação do marido. Nesse caso, percebemos que "a ficção se constrói labirinticamente em busca do Outro, exibe seus artifícios e inscreve a diferença nas suas escolhas formais" (Olivieri-Godet, 2007:234).

No início do século XXI, o questionamento da violência de gênero é retomado por diferentes prismas. Destacamos a perspectiva afro-brasileira de Conceição Evaristo que retrata a violência doméstica, no romance Ponciá Vicêncio (2002), relacionando-a à estrutura capitalista de opressão à mulher negra; e a performance estética como Nélida Piñon, em Vozes do deserto (2004), retoma o tema do feminicídio por meio de uma paródia do imaginário árabe. Essas representações possibilitam diferentes debates acerca da estrutura social que dá sustentação à violência 
de gênero até os dias atuais, pois se opõem a regras sociais que valorizam a masculinidade como sendo "aquela que tem a iniciativa e que se apodera unilateralmente do corpo do outro" (Machado, 1998:234).

Como recorte, este artigo analisa os significados do sacrifício da mulher na visão paródica de Vozes do deserto. Nélida Piñon, nessa obra, propõe um olhar revisionista e feminista que contesta o sacrifício da mulher e desloca as identidades de Scherezade e do Califa para espaços subjetivos e flexíveis. Além disso, esse romance é atravessado pelas peculiaridades pós-modernas ao fazer referência a um constante processo metaficcional que ressalta o deslocamento dessas personagens. ${ }^{1}$

Didaticamente, dividiremos este trabalho em dois momentos: no primeiro, exploraremos alguns conceitos antropológicos que classificam as diferentes regulações de violência de gênero para interpretar a resistência feminista da protagonista diante do horror da execução; no segundo, vamos investigar a estrutura literária pós-moderna $e$ o descentramento identitário da protagonista como uma maneira de contestação do passado. Com esses tópicos, discutiremos as contribuições dos estudos antropológicos e da crítica literária para a ampliação dos sentidos da violência contra a mulher a partir do modelo literário paródico. Com metas interdisciplinares, exploraremos os conceitos: "feminicídio", "crise de masculinidade", "violência estrutural de gênero", "paródia" e "corpo liberado", propostos pelas pesquisadoras femininistas Lia Zanotta Machado, Henrietta Moore, Rita Segato, Linda Hutcheon e Elódia Xavier, respectivamente.

Esse processo de revisão do passado por meio de uma obra paródica, que brinca com sua condição de arte enquanto dá voz aos marginalizados, é própria da narrativa pós-moderna de

1 Este texto traz os resultados parciais de uma pesquisa de pós-doutorado desenvolvida junto ao Programa de Pós-Graduação em Antropologia Social da UnB, supervisionada por Lia Zanotta Machado, acerca do feminicídio na literatura brasileira, com financiamento do $\mathrm{CNPq}$. 
autoria feminina no Brasil (Gomes, 2010). Por explorar dados e conceitos próprios da antropologia, procuramos analisar o texto literário como um modelo de questionamento cultural. Essa prática de interpretação nos convida a expandir o estudo da relação entre texto e história por meio dos estudos comparados que valorizam os aspectos ideológicos como arquivos literários. Essa retomada de um tema ancestral, o sacrifício da mulher, por meio de uma abordagem paródica, reforça o quanto a intertextualidade é dinâmica ao brincar com aspectos ideológicos da obra original (Samoyault, 2008).

No caso da ficção de Nélida Piñon, por ser um texto que contesta a violência de gênero, identificamos uma relação intertextual subversiva, na qual o texto original é retomado de um lugar marcado pelo olhar feminista. Tal peculiaridade entre o texto da brasileira e o imaginário árabe abre o debate acerca de como a paródia pode ser usada como uma faceta estética de contestação das normas impostas. Assim, este estudo valoriza o processo da "intertextualidade da diferença", identificada em textos recepcionados por meio de um processo literário rebelde que busca autonomia e independência (Sant'Anna, 2007:32).

Metodologicamente, aplicamos o conceito de gênero como uma categoria que define uma relação socialmente construída entre homens e mulheres, levando em conta as subjetividades dessas escolhas: "a questão de gênero implica não só o modo pelo qual "eu/ele" me constituo como estilo feminino, masculino, como "eu/ele" penso etc., mas também implica em determinadas formas de sexualidade que exercem" (Machado, 2014:16). No debate sobre identificações masculinas e femininas, ressaltamos a relevância das subjetividades como complemento das normas de gênero e dos valores morais que regulam o espaço social, uma vez que

os indivíduos constituem seu sentido de si mesmos - suas autorrepresentações como sujeitos - por referência a várias posições de sujeito frequentemente contraditórias entre si $e$ não a uma posição singular de sujeito (Moore, 2000:23). 
No estudo do romance de Nélida Piñon, isso só é possível pelo deslocamento das personagens centrais do imaginário árabe, que vão mudando seus interesses sexuais à medida que negociam os limites da violência de gênero. Esse debate acerca do que está em jogo na execução de uma mulher é muito importante para pensarmos os atuais feminicídios como uma herança maldita de valores patriarcais pautados pela valorização da honra masculina, como veremos na sequência.

\section{O sacrifício como parte da estrutura social}

Por questionar o espaço patriarcal, Vozes do deserto abre um debate acerca dos diferentes mecanismos de violência no espaço doméstico. A estreita relação entre o romance brasileiro e a fábula árabe nos convida a uma reflexão sobre a performance estética de Piñon, que explora intertextos ideológicos que deslocam a protagonista árabe para um espaço contemporâneo de resistência. Ao não se entregar ao destino trágico, Scherezade luta pelo fim dos castigos impostos. Esse contexto narrativo se aproxima da violência doméstica, na qual as mulheres são vítimas de atos crônicos que passam por agressões e assédios, produzidos pela tentativa de manter a ordem e a supremacia masculinas (Machado, 2010).

Os estudos antropológicos estão dando mais visibilidade às questóes referentes ao assassinato de mulheres por ser um tema recorrente e assustador. Esses estudos têm associado o feminicídio às normas estruturais hegemônicas de imposição da masculinidade como um padrão de controle pela força e pela agressividade. A principal diferença do feminicídio para o homicídio banal de mulheres está relacionada à exploração do corpo da mulher como uma extensão do desejo masculino. Esse crime, muitas vezes, é antecedido de abusos verbais, físicos e privações (Pasinato, 2011:232). O feminicídio pode ser classificado como todo assassinato motivado por questões de punição, castigo ou vingança de um homem contra uma mulher, tanto em relações 
afetivas quanto em crimes praticados por desconhecidos (Segato, 2003; Pasinato, 2015).

A repetição quase cotidiana de feminicídios aponta para um dispositivo hegemônico, visto que são executados como normas culturais, simbólicas e sociais, nas quais o poder e a força masculinos são privilegiados. Para a antropóloga Rita Laura Segato, esses crimes "não são obra de desvios individuais, doentes mentais ou anomalias sociais, mas de expressões de uma estrutura simbólica profunda que organiza nossos atos e nossas fantasias $e$ confere-lhes inteligibilidade" (Segato, 2005:270).

A obra de Nélida Pinõn retoma esse tema para expor a tirania masculina por meio de uma performance feminista que interpela o abuso físico e sexual das mulheres em nome da honra. A versão brasileira focaliza o fio da história nos dilemas pessoais da contadora de histórias Scherezade, uma "vítima voluntária desta cadeia interminável de jovens assassinadas" (Piñon, 2004:72). Essa protagonista se doa ao sacrifício, casando-se com o Califa para seduzi-lo por meio de suas narrativas: "desde que o terror se difundira pelo reino... Scherezade decidira opor-se a tal crueldade" (Piñon, 2004:29). Ao suspender a história com o amanhecer, ela deixa que a curiosidade tome conta do soberano, que lhe dá mais um dia de vida para ouvi-la novamente na noite seguinte.

$\mathrm{Na}$ fábula árabe, o sacrifício do corpo feminino é imposto como punição coletiva para as mulheres. Isso acontece assim que o Califa descobre a traição da Sultana. Como castigo, ele não só condena a esposa à morte como impõe que as novas esposas, depois da primeira noite de núpcias, sejam executadas ao amanhecer. Nesse contexto, ao corpo feminino são impostas a disciplina $e$ a submissão às regras patriarcais, mantidas pelo Estado e pela família (Xavier, 2007:59). Os primeiros dias de Scherezade no Castelo são cercados por essa tirania do corpo disciplinado e pela ameaça da execução:

Nada o comovia. Nem mesmo o rosto aterrorizado a pedirlhe clemência, ao menos alguns dias de vida, enquanto o 
carrasco, decidido a silenciá-la antes que a morte o fizesse, amordaçava-a sem sinais de compaixão (Piñon, 2004:137).

O primeiro feminicídio deu lugar a um ritual que tinha algumas fases: a escolha da jovem virgem, o preparatório para o casamento, a noite de núpcias e a decaptação da esposa. Mesmo sabendo do perigo, a jovem Scherezade aceita se casar com o Califa, doando sua própria vida e sua criatividade na tentativa de subverter o ódio do soberano: "Aos seus gestos mesquinhos, cevados no abuso do poder, ela revida com as histórias" (Piñon, 2004:229). Tal estrutura de violência de gênero abrange contratos simbólicos de desvalorização da mulher e é marcada pela contradição social de cultuar o corpo feminino virgem, puro $e$ idealizado, enquanto prega o sacrifício do corpo fora dos padrões venerados (Segato, 2003:03).

No romance, o sacrifício é descrito como uma estratégia para evitar o possível adultério. Assim, após a consumação do casamento, o corpo da jovem passava a representar perigo, por ter perdido a pureza, e deveria ser executado, visto que ele passa a ameaçar a honra do Califa: "por ordem do soberano, nenhum sangue vil, criminoso e traidor, além de jovens, mancharia o piso de mármore diariamente preparado para a cerimônia de execução das esposas" (Piñon, 2004:11). A tirania do soberano prevalece até a chegada da jovem contadora de histórias. Cercada pelo medo $e$ pelo perigo da morte, essa protagonista se sente vitoriosa a cada manhã, após adiar seu sacrifício.

Os detalhes da limpeza do espaço da execução contrastam com a brutalidade que dá sustentação à decaptação de um corpo inocente. Tal cuidado expõe o quanto o terror é usado para controlar o comportamento das mulheres. $\mathrm{O}$ sacrifício de inocentes expõe os perversos mecanismos de controle das normas de gênero. Esse ato é uma tentativa desesperada de reconquistar a honra perdida do soberano: "O cadafalso, de construção esmerada, fora erguido com a finalidade única de servir às jovens esposas do Califa, condenadas ao amanhecer" (Piñon, 2004:11). Ao privilegiar o zelo e a limpeza do espaço da execução, Piñon 
reforça a importância do sacrifício como um ritual de purificação do reino, remetendo-nos à relação moralizante entre o adultério feminino e feminicídio.

Com uma estratégia revisionista, Vozes do deserto questiona a punição como uma estratégia de manutenção da honra masculina, convidando o leitor a uma reflexão sobre a violência a partir da crise de masculinidade do Califa, um vez que a punição é imposta com a finalidade de recuperação de sua honra, fragilizada com o adultério da Sultana. Nesse processo de vingança, vêm à tona as fragilidades masculinas com

a incapacidade de manter a fantasia de poder provoca uma crise na fantasia de identidade, e a violência é um meio de resolver essa crise porque age reconfirmando a natureza de uma masculinidade de outra maneira negada (Moore, 2000:43).

Essa reconfiguração só será possível a partir do momento em que o soberano passa a sentir prazer pelas fábulas narradas por sua jovem esposa Scherezade: "mantendo o interesse do Califa até o amanhecer" (Piñon, 2004:35).

$\mathrm{Na}$ luta pela liberdade, a protagonista sofre diferentes assédios psicológicos e sexuais. Sem privacidade, ela precisa esconder suas angústias diárias: "Reunidas nos aposentos, Scherezade mal dissimula a náusea. $\mathrm{O}$ medo que sente lhe acentua o desconforto provindo do convívio forçado com as escravas" (Piñon, 2004:12). Essas mulheres encarceradas retratam uma estrutura de gênero que as empurra para os sombrios territórios do sacrifício (Segato, 2003:08). Nesse universo ficcional, a representação do sacrifício está relacionada a um padrão cultural de controle e de disciplina das mulheres, no qual "a dominância de um pensamento que entende a sexualidade polarizada entre uns que são sujeitos $e$ outras que são objetos maculáveis $e$ sacrificiais parece ter os efeitos cruéis" (Machado, 1998:250).

A punição às jovens do Califado ocorre porque a honra do soberano foi atingida pela traição da Sultana. Nesses casos, não só 
os valores pessoais estão em jogo, pois há um padrão cultural a ser respeitado. Assim, a crise pessoal é "resultado do conflito entre estratégias sociais que estão intimamente ligadas a esses modos de representação" (Moore, 2000:41). A traição é vergonhosa no contexto patriarcal. Para um soberano é duplamente vergonhosa, como homem e como líder. Com um propósito paródico, Nélida Pinõn explora os detalhes desse soberano que não esquece a vergonha sofrida, expondo sua fragilidade: "o fantasma da Sultana, nesta mútua perseguição, deblatera, indaga em nome de que princípio o Califa lhe decretara a morte. E por que motivo não libertava as mulheres" (Piñon, 2004:196).

Com o prazer alcançado com as narrativas de Scherezade, o soberano tem a oportunidade de repensar o sentido do sacrifício imposto, já que a postura persuasiva dessa narradora descentra seus valores morais hegemônicos. Essa mudança de postura do Califa é o ponto chave da versão de Nélida Piñon, que propõe também uma reflexão sobre a relativização das relações de poder, que são exercidas de maneira transversal, fazendo com que "existam diferentes experiências de ser mulher, de ser homem e de vivência da violência" (Pasinato, 2011:239).

Ao descrever uma narradora corajosa e um soberano em crise com o fantasma da traição, esse romance retoma um dos problemas que dão sustentação simbólica ao alto número de assassinato de mulheres: a insegurança masculina. Esse comportamento é comum àqueles que têm a "incapacidade de controlar o comportamento sexual de outras pessoas, isto é, a administração que outras pessoas fazem de si mesmas enquanto indivíduos marcados por gênero" (Moore, 2000:39).

A vergonha provocada pela traição dá sustentação ao ódio do Califa por ter perdido o controle da sexualidade da Sultana. Ao ser traído, fica desrespeitado publicamente e magoado:

a dor do Califa, que lhe vem aguda em torno de doze horas, quando o sol queima Bagdá, não provém de um amor ofendido. Há muito deixara de querer a esposa que o traíra miseravelmente no passado (Piñon, 2004:45). 
Aos poucos, o texto retoma os principais elementos que desnudam a violência de gênero como dispositivo de vingança $e$ punição da mulher.

$\mathrm{Na}$ ficção, como no contexto social, a violência contra a mulher é consequência da falta de confiança do homem em si. Desacreditado moralmente, ele impõe o sacrifício do corpo feminino como uma estratégia para reaver seu poder perdido. Todavia, esse desejo não é retomado, já que o fantasma da traição passa a persegui-lo, mesmo depois de executar outras jovens esposas: "No salão do trono, protegido das intempéries humanas, os gestos do Califa são confusos. Quer borrar o retrato da mulher fornicando com o colosso negro, em sua casa, à luz do sol" (Piñon, 2004:135).

Sem conseguir anular o passado, o soberano encontra uma saída para suas angústias, viajando pelas fabulosas histórias narradas. Dentro do processo de flexibilização da identidade masculina, observamos que o contato do Califa com o universo imaginário de Scherezade lhe traz novos sentidos para sua identidade. Isso fica claro no momento em que a jovem esposa passa a ser substituída na cama por sua irmã, Dinazarda. Se a farsa e a traição não eram aceitas, aos poucos elas passam a ser relativizadas pelo Califa, pois "como se havendo saciado a sede de vingança, o castigo impingido às mulheres já não lhe traz o júbilo de antes" (Piñon, 2004:327). Ao se afastar do fantasma da honra ferida, o soberano se distancia de seu fantasma interno, o medo de perder seu poder entre as mulheres.

Essa perspectiva de mudança de identificação do Califa é inovadora na versão de Piñon, visto que ele é traído pelas belezas das narrativas, passando "a viver em regime de farsa em troca das compensações habituais, constituídas dos relatos de Scherezade" (Piñon, 2004:332). A mudança de comportamento também vai se refletir na performance sexual do Califa, que passa a vivenciar conflitos pessoais ao perceber que Scherezade não tem prazer com ele. As contradições desse sujeito reforçam o quanto a identidade de gênero não está sujeita ao padrão imposto culturalmente. 
No jogo de adiamento da morte da contadora de história, o Califa é seduzido e, consequentemente, traído pelo prazer de ouvila. Fora de controle, o ritual do sacrifício dá lugar a questionamentos sobre o aprisionamento da narradora: "ultimamente o Califa vinha se perguntando se não chegara o momento de tentar viver sem Scherezade" (Piñon, 2004:340). Esse reconhecimento reforça a importância da luta da mulher, que não se dobra diante do terror imposto pela possível execução. A voz dessa personagem é ouvida e o sacrifício deixa de ser praticado, após o reconhecimento do soberano de que o júbilo de antes era uma fantasia pessoal que não tem mais significação.

Além da crise da masculinidade, o romance de Piñon deixa pistas para reavaliarmos o papel do Estado e das comunidades diante da violência de gênero. $\mathrm{O}$ debate sobre a omissão do Estado, no caso dos crimes de gênero, é fundamental para avançarmos na manutenção dos diretos da mulher. Desse modo, ao propor uma obra que questiona esses crimes impostos por um soberano, mesmo sendo um contexto fabuloso, o romance de Piñon abre diversas possibilidades para repensarmos os elementos sociais e simbólicos que dão sustentação a esse tipo de sacrifício.

Os valores morais do romance de Piñon não são muito diferentes da realidade de hoje, pois a fábula do terror de gênero ainda acontece cotidianamente no Brasil e em diversas localidades do mundo. Seja no sequestro de meninas para serem escravas sexuais, seja em estupros coletivos em que o corpo da mulher é usado como um fetiche machista de tortura sexual por um grupo de homens. Em situações como essas, os direitos da mulher são desrespeitados, prevalecendo a força da masculinidade e sua busca de prazer, conforme Gomes (2016b). Esse olhar crítico acerca de regras misóginas atravessa Vozes do deserto, retomando o tema da execução da esposa adúltera de forma inovadora, pois ironiza a questão da honra masculina.

$\mathrm{Na}$ ficção, por ser o sacrifício imposto por um soberano, líder de um povo, podemos associar a matança de mulheres a um crime de Estado, pois há uma omissão de todos diante da barbárie. Em recente estudo sobre crimes de gênero não julgados, 
nem punidos, Rita Laura Segato (2006) construiu o conceito de crime de Estado ou de corporação para essas situações em que a mulher é vítima de um sistema de governo. Ela parte de um estudo sobre o assassinato $e$ o desaparecimento de mulheres no México, em Ciudad Juárez, onde as autoridades não estavam interessadas em punir os culpados, nem a polícia em investigar tais crimes. Essa situação de omissão é própria da estrutura legislativa que encobre ou deixa de investigar propositadamente, ou de comum acordo, os crimes contra mulheres.

No romance Vozes do deserto, há completa omissão dos participantes do Califado acerca da barbárie imposta às mulheres transgressoras. Cabe às vítimas lutarem para se salvar do trágico destino imposto pelas normas sociais. Particularidade que reforça a relevância da releitura feminista dessa obra, que explora o feminicídio como um crime de Estado, isto é, aquele cometido ou aceito por "um grupo ou rede que administra os recursos, direitos e deveres próprios de um Estado" (Segato, 2005:283). Assim, os fatos narrados descrevem um típico genocídio de mulheres como norma de punição e controle da sexualidade das mulheres. Isso fica mais explícito ao relacionarmos a crise da masculinidade como uma metáfora da crise dos homens do Califado.

Essa reversão de valores só acontece porque, no processo de releitura do passado patriarcal, o romance abre espaço para trabalhar com a subjetividade das identidades em jogo, pois a identidade de gênero passa pelo modo como essas personagens se constroem como feminino e masculino conforme suas crises pessoais. Tal construção é atravessada por diferentes opções subjetivas de discursos e práticas sociais de "sujeitos multiplamente constituídos", podendo assumir "múltiplas posições" (Moore, 2000:22).

No romance, a maneira como a masculinidade e a feminilidade são exercidas é indício do quanto as posições de suas personagens são ajustadas para a superação da violência. $\mathrm{Na}$ versão de Nélida Piñon, à medida que assume o papel de narradora, Scherezade se distancia do papel de amante. Sua falta de habilidade na cama é percebida pelo marido que passa a 
admitir outras mulheres em seu lugar. Com isso, as irmãs e uma escrava tornam-se cúmplices e trocam suas posições no leito do soberano:

Dinazarda serviria ao Califa na cama, enquanto a escrava Jasmine, recém-descobrindo a tardia vocação de contadora, iria entreter o soberano com histórias que há muito tinha no caldeirão da bruxa, como considerava sua memória (Piñon, 2004:347).

Na reta final do romance, Scherezade é substituída pelas duas que passam a exercer seus papéis: a irmã na vida sexual e a escrava na construção de novas narrativas.

Portanto, a partir dos estudos feministas, reconhecemos que a releitura do imaginário árabe, proposta por Nélida Piñon, produz uma performance pós-moderna de revisão do passado, questionando as desigualdades de gênero $e$ as normatizações ideologicamente impostas como verdades naturalizadas por um grupo dominante. Suas estratégias narrativas pós-modernas se aproximam da perspectiva de um feminismo de resistência que explora "ações transversais que percorrem todas as esferas políticas e sociais" (Pasinato, 2015:542).

Nesse caso, a reescrita do tema passa pelo olhar atento da escritora que brinca com as tradições ao desmascarar a intimidade de um Califa em crise com sua honra. Com as especificidades de uma obra paródica, estamos diante de uma "intertextualidade da diferença", pois o texto atual se opõe ao texto original, assumindo um lugar de rebeldia, próprio de obras transgressoras (Sant'Anna, 2007:20).

Na sequência, passamos a debater as relações da estrutura literária pós-moderna com o descentramento das personagens a partir da exploração das características do texto paródico. Especificamente, interessa-nos identificar as sutilezas formais usadas por Nélida Piñon para questionar os valores misóginos. 


\section{A revisão do passado como prática de resistência}

Neste tópico, destacaremos as características pós-modernas do romance Vozes do deserto por sua performance política feminista. A narrativa literária pós-moderna tem a peculiaridade de apresentar diversas instâncias sendo questionadas na própria construção do texto, como a fragmentação da identidade do narrador $e$ dos limites ficcionais $e$ culturais do texto. A instabilidade passa a fazer parte do estatuto dessa literatura que privilegia, entre outros recursos, a metanarratividade e seu caráter paródico. Essas estratégias narrativas desestabilizam a homogeneidade em torno do narrador e dos limites do texto ficcional.

No texto de autoria feminina, esse duplo movimento possibilita diversas reflexões sobre a relação entre personagens femininas $e$ autoras politicamente defensoras dos direitos das mulheres. Essa estratégia política fortalece a proposta artística que trata menos de arte e mais de questionar os mecanismos de opressão da mulher, pois esse jogo estético da repetição é explorado a serviço de um caráter revisionista (Campello, 2006). No caso do texto paródico de autoria feminina, esse movimento de revisão e questionamento da opressão da mulher tanto é identificado na estrutura textual como na proposta feminista de contestação do patriarcado (Gomes, 2010).

Vozes do deserto propõe a revisão do passado patriarcal por meio da reescrita do imaginário árabe por um prisma feminista contemporâneo, pois privilegia o ponto de vista da contadora de histórias de Mil e uma noites, Scherezade. No romance brasileiro, por se doar ao sacrifício, essa protagonista se projeta como um sujeito feminino de resistência que aprendera essa arte da contadora de histórias com "Fátima, a ama que, após a morte prematura da mãe, ensinara-lhe a contar histórias" (Piñon, 2004:8). Nessa empreitada, terror e referências ao processo narrativo se intercalam. Sua proposta é tentar adiar a morte anunciada por meio de sua criatividade: "em torno da jovem floresciam sentimentos na iminência de desembocar em um desfecho 
trágico" (Piñon, 2004:9). Esse processo de execução é identificado em sociedades que desprezam o corpo feminino, pois "com o desprezo pelo corpo cresceu também o desprezo pela mulher" (Xavier, 2007:132).

Com o ímpeto de livrar as mulheres do ritual do sacrifício, Scherezade escavava o imaginário para seduzir o Califa: "suas histórias, semeadas de atitudes heroicas e imprudentes, saciam os ouvintes famintos, mantendo o interesse do Califa até o amanhecer" (Piñon, 2004:35). A arte de contar era a única arma que tinha para sobreviver. A cada dia um novo desafio, por isso usava estratégias sedutoras para despertar o prazer do ouvinte, que, atraído pelo desfecho da história suspensa, dava-lhe mais um dia de vida.

Essa estratégia de dar voz a uma mulher, parodiando o poder masculino e suas representações opressoras, tornou-se uma marca da literatura de autoria feminina pós-moderna que fragmenta as questões ideológicas hegemônicas (Hutcheon, 1993:9). No romance de Piñon, a polifonia de vozes femininas condensadas na luta da protagonista fortalece sua performance política, pois nos remete à luta das mulheres que estavam sujeitas ao feminicídio. Esse jogo de vozes também pode ser identificado como uma "poética da alteridade", isto é, o romance pósmoderno se articula em torno da possibilidade de a autora se reconhecer na voz de outras mulheres (Olivieri-Godet, 2007:237).

No processo ficcional de Piñon, narrar significa buscar um caminho para a liberdade, já que todos os dias, a protagonista estava jurada de morte. O romance se projeta como uma arte de resistência, já que narrar é também a arte de se salvar. Essa aproximação do "eu" da narrativa com as causas da mulher ressalta a performance feminista dessa obra, que nos remete a uma metanarratividade crítica, uma vez que

a projeção do eu da artista e do mundo estabelece relações de similitude entre essa projeção e outros tipos de representação, extra e intradiegéticos, o que resulta em uma 
cadeia, em abismo, de significações (myse-en-abyme) (Campello, 2006:129).

O romance de Piñon deixa o fio da metanarratividade vir à tona ao registrar o cuidado com o processo de construção das infinitas histórias da protagonista: "Quase perdida, agarra-se às metáforas que lhe vêm ao encalço" (Piñon, 2004:53). A referência ao ato de narrar expõe traços da autorreflexão crítica, fortalecendo a capacidade de fabular de Scherezade que ganha espaço nas noites do soberano: "para que não decresça o interesse do Califa, implanta no enigmático homem um vício que o impede de libertar-se da volúpia de ouvir seus contos" (Piñon, 2004:214). Ao falar da volúpia do texto narrado, a obra retoma o mosaico de intertextos com o qual é composta, convidando o leitor a saborear diferentes intertextos culturais que precedem a versão de Piñon, conforme estudos de Gomes (2016a).

Nesse sentido, esse romance explora a metanarratividade por uma via dupla: fala do ato de narrar, dando destaque à identidade feminina que se reconstrói por meio do texto que está sendo contado. A relação da narrativa com a salvação da protagonista nos traz uma metáfora do quanto a literatura/arte pode vencer a violência masculina. Nesse contexto adverso, a criatividade e a união das mulheres eram usadas como estratégias de resistência: "Sem ele [Califa] perceber que a meta da jovem era jamais deixar os fios soltos do relato no ar, de modo a poder atálos na noite seguinte" (Piñon, 2004:27). Esse tipo de narrativa "direta ou indiretamente vincula-se à arte, à moral, à ética e à ideologia" (Campello, 2006:129). Portanto, é nesse sentido que esse romance traz rastros do estilo pós-moderno ao ser metaficcional e ideologicamente marcado pela luta da liberdade feminina.

Com a postura transgressora da narradora, Vozes do deserto não busca apenas repetir o enredo original, mas deslocar a mulher no contexto patriarcal, que passa a ser guiada por seu desejo. Essa postura transgressora é uma das marcas dessa obra que traz uma visão paródica do texto árabe por funcionar, esteticamente, como um contraestilo, que desloca as coisas do lugar comum (Sant'Anna, 
2007:29). Seguindo essa linha de pensamento, temos um romance metaficcional que apresenta um ruído do texto recepcionado, dando pistas de sua proposta de problematizar a narrativa anterior.

No processo narrativo, a construção da identidade da protagonista se confunde com a do texto narrado. Esse processo identitário atravessa toda a obra:

Mas enquanto Scherezade ia narrando os infortúnios dos personagens, as palavras da verdade ficcional a fortaleciam. Igual a Polixena, brotava-lhe do peito um grito que, diante da adaga na garganta, ameaçava jamais se extinguir (Piñon, 2004:278).

A relação da protagonista com a luta pela liberdade da mulher é contínua. Ela não abre mão de se sacrificar pelas outras jovens.

Depois de vencida sua luta pelo fim do sacrifício das esposas, essa protagonista se mostra insatisfeita com os limites do palácio: "Chegara, pois, o momento de Scherezade partir. De seguir viagem, obedecendo às instruções de seu recalcado desejo" (Piñon, 2004:343). Essa opção reforça o quanto sua identidade é transitória, por isso projeta a busca de outro espaço todo seu, uma heterotopia, sugerindo que a voz da mulher é ouvida e o castigo suprimido, chegando a hora do fim dos feminicídios do califado.

Apesar da trágica história de feminicídio, marcada pelo assédio e o horror da execução, que perdura durante quase toda a trajetória da protagonista, a narrativa de Piñon projeta o corpo feminino fora daquela prisão, ao propor o final de liberdade da protagonista. Ela "cruzaria o deserto distraindo-se com os animais, em especial os camelos" (Piñon, 2004:347), com a finalidade de reencontrar sua ama, Fátima, "que a recebera de braços abertos tão logo chegou à casa, poeirenta, faminta, mas feliz" (Piñon, 2004:351). Depois de longas noites de narrativas, Scherezade alcança sua liberdade. 
A construção da identidade feminista de resistência está marcada desde o início da obra que retrata uma jovem que, à medida que consegue se defender $e$ adiar sua morte, vai se fortalecendo e se projetando fora daquele espaço opressor. Nesse sentido, podemos classificar Scherezade como uma personagem em trânsito por recusar a limitação das fronteiras patriarcais, assumindo a "inconstância, a transição $e$ a posição 'entre' identidades como intensificadoras do desejo" (Louro, 2008:22). Mesmo diante de normas rígidas, ela opta por comportamentos avessos ao padrão imposto, mostrando-se insatisfeita com a vida no califado.

A projeção de Scherezade fora dos espaços do palácio reforça a releitura feminista que dá sustentação ao romance de Piñon. Por ter um tom de rebeldia desde o início da narrativa, respaldado pelo olhar feminista que brinca com o passado ao descrever um tirano frágil e inseguro, essa obra pode ser vista como uma filha rebelde "que quer negar sua paternidade e quer autonomia e maioridade" (Sant'Anna, 2007:32). Assim, essa dupla conquista se concretiza com a libertação da protagonista do destino imposto pelo Califa.

Por conseguinte, a relação intertextual entre o texto árabe $e$ o de Piñon pode ser ampliada pela capacidade de o segundo iluminar a interpretação do primeiro, possibilitando novos sentidos para o cárcere privado, o abuso sexual e o assassinato de mulheres no contexto familiar. Nesse caso, o prisma feminista de contestação da violência de gênero retoma a intertextualidade como uma estratégia da diferença sem se desvincular da renovação de sentidos (Samoyault, 2008:47).

Insatisfeita, a protagonista de Piñon passa a se projetar para fora do califado, enquanto se volta para dentro de si. Essa viagemrefúgio tem também um duplo sentido nessa obra, pois desqualifica o local da violência, enquanto delineia um território de resistência. Nesse processo de deslocamentos identitários, o romance não propõe uma saída simples, pois opta por deixar a protagonista livre, mas errante no novo mundo de liberdade, sem uma chegada fixa, pois "não há um lugar de chegar, não há um 
destino pré-fixado, o que interessa é o movimento e as mudanças que se dão ao longo do trajeto" (Louro, 2008:13).

Para Elódia Xavier (2007), essa perspectiva artística do deslocamento das personagens femininas para fora dos espaços opressores só passou a ser representada nos textos de autoria feminina brasileira no final do século XX. Nesse caso, o corpo da mulher para a ser um "corpo liberado", visto que a mulher abandona o sistema disciplinador para viver em plena liberdade. Portanto, esse outro espaço heterotópico, fora do califado, é uma marca contemporânea dessa obra que abre espaço para o corpo liberado da protagonista que busca sua plenitude pessoal longe das amarras do palácio do Califa.

O deslocamento dessa personagem de história clássica por uma obra pós-moderna reforça sua condição de revisão do passado, desafiando a voz hegemônica do patriarcado $e$ questionando os limites da representação a partir da política de valorização da identidade da mulher (Hutcheon, 1993:5). Portanto, a contextualização da luta da mulher por seus direitos e a paródia da crise de masculinidade do Califa fortalecem a proposta política feminista do texto atual. Tal polifonia de vozes femininas nos remete a "contextos transnacionais" - um espaço de valores $e$ interesses comunitários - já que a escrita está interseccionada com as preocupações feministas comuns às lutas contra a opressão $e$ pelos direitos da mulher, próprias do sujeito feminista transnacional (Campello, 2006:132).

\section{Considerações finais}

Ao lermos Vozes do deserto como uma revisão crítica da cultura patriarcal, identificamos a irreverência paródica como uma estratégia de questionamento de normas sociais opressoras. Esse modelo ganha o ajuste do olhar feminista que desconstrói o universo do patriarcado para propor um espaço de liberdade $e$ criatividade para as mulheres. Tais aspectos pós-modernos podem ser identificados pelo uso da metanarratividade, do humor e da irreverência, como recursos estéticos; $e$ da fragmentação 
identitária e da resistência feminista, como recursos ideológicos. Assim como as obras de Clarice Lispector e Lygia Fagundes Telles, citadas neste artigo, esse romance desloca esteticamente a mulher para questionar a violência imposta por padrões morais hegemônicos (Gomes, 2014:792).

As peculiaridades da representação de Nélida Piñon reforçam o processo de recepção criativa do imaginário árabe por meio da abordagem paródica. Por isso, ao rever o passado por meio de uma visão irônica, essa obra imprime um ritmo político de denúncia da violência contra a mulher por meio de personagens subversivas, reforçando a estratégia de desconstrução de valores morais hegemônicos. Essa performance estética é própria de uma postura questionadora dos romances pósmodernos (Hutcheon, 1993:09).

Dentro da tradição dos estudos comparados, destacamos o quanto Nélida Piñon reescreve a obra do imaginário árabe pelo prisma feminista e contemporâneo, ao abrir o debate sobre o feminicídio em contextos patriarcais. Tal postura questionadora é identificada em seu duplo lugar de fala: descreve o projeto metanarrativo ao mesmo tempo que valoriza a voz da mulher oprimida. A particularidade dessa estética reforça sua performance feminista de revisão do passado, desregulando normas de gênero hegemônicas (Gomes, 2017). Isso foi possível porque o texto de Nélida Piñon ressalta conexões culturais e estéticas, que dinamizam o processo de recepção, "destemporalizando" a obra anterior que passa a ser usada como parte da contemporaneidade (Samoyault, 2008:95).

Assim, Vozes do deserto se apresenta como uma revisão de práticas ancestrais, repudiando o absurdo do feminicídio como estratégia masculina de defesa da honra. Além disso, relendo a fábula oriental, Piñon atualiza seus sentidos, brincando com a perspectiva machista e opondo-se à discriminação de gênero como um "padrão cultural que é aprendido e transmitido ao longo de gerações" (Pasinato, 2011:230). Por projetar uma interpretação feminista subjetiva e criativa, Piñon desmascara os mecanismos de controle de gênero, quando deixa nu o tirânico discurso da 
vingança pela honra. Com essa versão paródica, os valores patriarcais atávicos são expostos como fantasmas moralistas que escamoteiam a crise da masculinidade por trás do feminicídio.

Apesar de ser herança ancestral de regulações de gênero, a postura vingativa do Califa ainda é um comportamento muito comum na sociedade brasileira. Essa normatização é metaforicamente questionada no texto pós-moderno de Piñon, com um soberano em crise e uma esposa que lhe convence que sua violência não é suficiente para livrá-lo de sua falta de confiança em si. Com essa opção estética, Vozes do deserto ressalta a força do grito da mulher e seu poder de luta pela liberdade de escolha e decisão de livre arbítrio.

\section{Referências bibliográficas}

CAMPEllo, Eliane T. A. O Künstlerroman de autoria feminina no Brasil. In: CAVALCANTI, Ildney et alii (org.). Da mulher às mulheres: dialogando sobre literatura, gênero e identidades. Maceió, Edufal, 2006, pp.125-133.

Evaristo, Conceição. Ponciá Vicêncio. Belo Horizonte, Mazza, 2003.

GOMES, Carlos Magno. A alteridade no romance pós-moderno. São Cristóvão, Editora da UFS, 2010.

. O femicídio na ficção de autoria feminina brasileira. Revista Estudos Feministas vol. 22 (3), Florianópolis, UFSC, 2014, pp.781794.

Intertextos e mediações culturais em Nélida Piñon. Scripta vol. 20 (39), Belo Horizonte, PUC-MG, 2016a, pp.277-290.

. A violência de gênero e a crise de masculinidade. Fórum Identidade vol. 21, Itabaiana, UFS, 2016b, pp.33-48.

- Literatura e performances políticas sobre a violência contra a mulher. Pontos de Interrogação, Revista de Crítica cultural do Programa de Pós-Graduação em Crítica Cultural, vol. 7, $\mathrm{n}^{\circ} 2$, Alagoinhas, UNEB, 2017, pp.107-119. 
HUTCHEON, Linda. La política de la parodia postmoderna. Revista Criterios. La Habana, edición especial, 1993, pp.187-203. [Traducción del inglés por Desiderio Navarro].

LisPeCTOR, Clarice. A língua do p. In: LisPECTOR, Clarice. A via crucis do corpo. Rio de Janeiro, Rocco, 1998, pp.67-70.

LOURO, Guacira Lopes. Um corpo estranho. Belo Horizonte, Autêntica, 2008.

LUFT, Lya. As parceiras. 28. ed. Rio de Janeiro, Record, 2014.

MACHADO, Lia Zanotta. Masculinidade, sexualidade e estupro. cadernos pagu (11), Campinas-SP, Núcleo de Estudos de GêneroPagu/Unicamp, 1998, pp.231-73.

. Feminismo em movimento. São Paulo, Francis, 2010.

. Interfaces e deslocamentos: feminismos, direitos, sexualidades e antropologia. cadernos pagu (42), Campinas-SP, Núcleo de Estudos de Gênero-Pagu/Unicamp, 2014, pp.13-46.

MoORE, Henrietta L. Fantasias de poder e fantasias de identidade: gênero, raça e violência. cadernos pagu (14), Campinas-SP, Núcleo de Estudos de Gênero-Pagu/Unicamp, 2000, pp.13-44.

OLIVIERI-GODET, Rita. Estranhos estrangeiros: poética da alteridade na narrativa contemporânea brasileira. Estudos de literatura brasileira contemporânea $\mathrm{n}^{\circ}$ 29, Brasília, UnB, 2007, pp.233-252.

PASINATO, Wânia. Feminicídios e as mortes de mulheres no Brasil. cadernos pagu (37), Campinas-SP, Núcleo de Estudos de GêneroPagu/Unicamp, 2011, pp.219-246.

. Oito anos de Lei Maria da Penha: entre avanços, obstáculos e desafios. Revista Estudos Feministas vol. 23 (2), Florianopólis, UFSC, 2015, pp.533-545.

Piñon, Nélida. Vozes do deserto. 2. ed. Rio de Janeiro, Record, 2004.

Samoyault, Tiphaine. $A$ intertextualidade: memória da literatura. São Paulo, Hucitec, 2008. [Tradução de Sandra Nitrini].

SANT'ANNA, Affonso Romano de. Paródia, paráfrase \& cia. São Paulo, Ática, 2007. 
SEGATO. Rita Laura. Las estructuras elementales de la violencia: contrato y status en la etiologia de la violencia. Série Antropológica. Brasília, Departamento de Antropologia da UnB, 2003.

. Território, soberania e crimes de segundo Estado: a escritura nos corpos das mulheres de Ciudad Juárez. Revista Estudos Feministas vol. 13 (2), Florianópolis, UFSC, 2005, pp.265-285.

. Que és un feminicidio: notas para un debate emergente. Série Antropológica. Brasília, Departamento de Antropologia da UnB, 2006.

Telles, Lygia Fagundes. Venha ver o pôr do sol. In: TELLES, Lygia Fagundes. Antes do baile verde. São Paulo, Companhia as Letras, 2009, pp.135-144.

XAVIER, Elódia. Que corpo é esse? O corpo no imaginário feminino. Santa Catarina, Mulheres, 2007. 